\title{
An Appraisal of Corporate Governance Issues in Enhancing Transparency and Accountability in Small and Medium Enterprises (SME)
}

\author{
Dr. (Mrs.) Ngozi ljeoma \\ Department of Accountancy, Nnamdi Azikiwe University, Awka \\ E-mail: ijeomangozi@ymail.com \\ Raymond Ezejiofor A. \\ Department of Accountancy, Nnamdi Azikiwe University, Awka \\ E-mail: thaddray4life@yahoo.com
}

DOI: $\quad 10.6007 /$ IJARBSS/v3-i8/134 URL: http://dx.doi.org/10.6007/IJARBSS/v3-i8/134

\begin{abstract}
This paper on "Corporate governance issues in enhancing transparency and accountability in small and medium enterprises" assess the to determine whether corporate governance contributes significantly in ensuring accountability and transparency in order to improve performances of an enterprise and to determine the extent at which corporate governance can facilitates the organizations in achieving their social responsibilities to the environment. The population for the paper was judgmentally selected from the management, staff of seven Small and Medium Enterprises (SMEs) in Anambra state, Nigeria. Data for the study were collected from both primary and secondary sources. The Hypotheses formulated for this paper were analyzed and tested with the Two Way ANOVA for opinion differences, using the Statistical Package for Social Sciences (SPSS) version 17.0 software package. The paper therefore conclude that corporate governance assists in provides structure through which the objectives of the SMEs are set and means of attaining those objectives and monitoring performances all to ensure effectiveness in operations and efficiency in their services.
\end{abstract}

Key Words: Corporate governance, Accountability, Transparency and SMEs

\section{Introduction}

Small and medium enterprises (SMEs) are engine of growth in prosperous and growing economy and play an important role in creating economic growth. SMEs contribute to economic development by creating employment for rural and urban population, providing flexibility and innovation through entrepreneurship and increase international trade by diversifying economic activity. Their role in income generation and economic growth for developing countries is critical. In the developed countries SMEs are major contributors to GDP and private sector employment contributing as much as $60 \%$ to workforce. In developing countries, they employ more than $70 \%$ of labor force. The abundance of labor and the 
shortages of capital which are characteristics of developing countries are comparable with the SMEs labor intensive character.

In general, corporate governance is considered as having significant implications for the growth prospects of an economy, because best practice corporate governance reduces risks for investors, attracts investment capital and improves the performance of companies (Spanos 2005). In Sri Lanka, effective corporate governance is considered as ensuring corporate accountability, enhancing the reliability and quality of financial information, and therefore enhancing the integrity and efficiency of capital markets, which in turn will improve investor confidence (Rezaee 2009).

Cadbury (1992) defined corporate governance as "the system by which companies are directed and controlled". It is concerned with the duties and responsibilities of a company's board of directors to successfully lead the company, and their relationship with its shareholders and other stakeholder groups. It is also defined as a "process through which shareholders induce management to act in their interests, providing a degree of investor confidence that is necessary for the capital markets to function effectively" (Rezaee, 2009).

However, when corporate governance is effective, it provides managers with oversight and holds boards and managers accountable in their management of corporate assets. This oversight and accountability combined with the efficient use of resources, improved access to lower-cost capital and increased responsiveness to societal needs and expectations should lead to improved corporate performance. Effective corporate governance is also closely related to efforts to reduce corruption in business dealings and make it difficult for corrupt practices to develop and take root in a company. Strong governance may not prevent corruption, but it should make it more likely that corrupt practices are discovered early and eliminated.

Unfortunately, some corporations are opportunistic and seek to profit, for example, from the use of child labour or without regard to environmental impact. Such examples represent not only failures of corporate responsibility and firm governance but larger failures of government to provide the framework needed to hold corporations responsible on issues that are important to a given society.

In view of this, the paper intends to determine whether corporate governance contributes significantly in ensuring accountability and transparency in order to improve performances of an enterprise.

ii. To determine the extent at which corporate governance can facilitates the organizations in achieving their social responsibilities to the environment.

\section{Review literature}

The last few decades have witnessed several changes in the world economic system: consolidating trend of globalization and liberalization of economies; crumbling barriers to international trade and free movement of capital due to the establishment of World Trade Organization (WTO) and shifts towards market economy in contrast to controlled or socialist economy. It was believed that market economy will be the 'mantra' for all nations, either developing or under developed, to achieve economic salvation. Destiny smiled and brought the believe into it's knee and rethinking process started afresh what ought to be the new 'mantra'. Economic downtown indicated further that it is not the big companies, which are only efficient machineries to rotate the economic circle; rather SME's are the most trusted vehicles that will 
lead any economy towards salvation but that realization has possibly not brought everything best for the SME's, rather it has opened up sea of challenges. There are new business orders in the advent of Information Technology- opening up of market dominated by medium and big domestic companies, transnational companies, which has brought new line of business strategies and supply chain, hitherto unknown to traditional business model which dominates the SME's sector.(Dibe et al, 20011).

Using a stakeholder approach, a firm is not just responsible to its owners or shareholders or members but also, to its constituency of stakeholders. These stakeholders include contractual partners, like employees, suppliers, social stakeholders, like the members of the community and the environment. This approach emphasizes long term performance, enhancing contributions by stakeholders and also view corporations as socially responsible institutions.

Thus, an appraisal of a firm will not only include financial performance but also employment, market share and growth in trading relations with suppliers and purchasers.

Corporate governance allows firms to prepare for their future expansion and sustainable growth. The core values of transparency and accountability will be embedded in their business culture. This culture of transparency and accountability will also indicate professional management and good governance for successful and well organized companies.

Introduction of good governance will improve SMEs' prospect of obtaining funds from banks, investors and venture capitalists. The presence of proper accounting and bookkeeping practices will increase confidence in the firm and make them less risky to invest or finance.

Firms that have information disclosure tend to have healthier growth rates and ratios of ordinary profits to that of capital, than firms who do not do so. Firms also will become increasingly committed to business efficiency due to the presence of external supervisory thirdparties.

Corporate governance is of growing importance, particularly with regards to the monitoring role of the board of directors. As a result much of the research into corporate governance derives from agency theory. Since the early work of Berle and Means (1932), corporate governance has focused upon the principal-agent problems arising from the dispersed ownership in the modern corporation. They viewed corporate governance as a mechanism where a board of directors is an essential monitoring device to minimize the problems brought about by the principal-agent relationship. In this context, agents are the managers, principals are the owners and the board of directors acts as the monitoring mechanism. The separation of ownership from management can lead to managers of firms taking action that may not maximize shareholders wealth, but could benefit them and not the owners. Hence a monitoring mechanism is required to protect shareholder interests (Jensen \& Meckling 1976).

In contrast to agency theory, stewardship theory presents a different model of management, where managers are considered good stewards who will act in the best interest of the owners (Donaldson, L \& Davis 1991). The fundamentals of stewardship theory are based on social psychology, which focuses on the behaviour of executives. Stewardship theory sees a strong relationship between managers ${ }^{\text {ec }}$ interests and the success of their firm, and therefore the stewards act to protect and maximize shareholder wealth. A steward, who improves performance successfully, satisfies most stakeholder groups in an organization, when these groups have interests that are well served by increasing organizational wealth (Davis, JH, 
Schoorman \& Donaldson 1997). Therefore, Monitoring and accountability can be provided by the adoption of corporate governance principles and practices.

\section{Business Ethics}

Business ethics is defined as a process for integrating values such as honesty, trust, transparency and fairness into its policies, practices and decision making. Business ethics is therefore inherently linked with corporate governance. The importance of business ethics cannot be denied. The old English proverb "as you sow so shall you reap" is indicative of the significance of business ethics. A firm which applies ethical practices also expects to be dealt ethically. These expectations and consequent adoption of ethical practices create chain effect in terms of promoting ethical practices. While the larger firms have already developed their reputation by adopting these ethics, SMEs around the world are increasingly becoming aware of the importance of good, trusting relationships with customers, employees, suppliers and the community. Moreover, due to their linkages with larger firms through supply chains SMEs are increasingly asked about their social and environmental policies when developing their ventures with large firms.

\section{The advantages of adopting business ethics}

1. Investors use corporate practices and values as primary considerations in their decisionmaking;

2. As customers are becoming increasingly aware of their rights, they value ethical practices. Adopting ethics can help to build reputation of businesses;

3. Promoting reputation can help in building customer loyalty and increase in revenue

4. Attracting talented workforce and employees as well as improved performance of existing employees increasing productivity

5. Compliance with regulations e.g. labour laws and environment etc

6. Collaboration with other firms both domestically and internationally

\section{Basic Principles of corporate governance and the OECD}

When the Business Sector Advisory Group issued its Report to OECD Ministers at the height of the Asian crisis, it recommended that the OECD promote and further articulate the "core standards" of corporate governance: fairness, transparency, accountability and responsibility. That proposal led the OECD to convene an Ad-Hoc Task Force on Corporate Governance comprised of representatives from the 29 OECD member nations as well as interested international organizations, and business and labour representatives. The Task Force also sought input from non-OECD nations (as well as broader public comment through its web site). In April of 1999 the Task Force issued a set of corporate governance principles that embody the consensus views of the Task Force members on the fundamentals. These Principles build on the four essentials articulated by the OECD Business Sector Advisory Group. While they are intended to be non-binding, they provide thoughtful guidance to nations seeking to improve corporate governance. (Holly and Marsha, 1999).

Fairness: The OECD Principles expand on the concept of "fairness" with two separate principles. Principle I states that: "The corporate governance framework should protect shareholders' rights." Generally, this Principle recognizes that shareholders are property owners, and as owners of a legally recognized and divisible share of a company, shareholders have the right to 
hold or convey their interest in the company. Effective corporate governance depends on laws, procedures and common practices that protect this property right and ensure secure methods of ownership, registration and free transferability of shares.

Principle I also recognizes that shareholder generally have certain participatory rights on key corporate decisions, such as the election of directors and the approval of major mergers or acquisitions. Governance issues relevant to these participatory rights concern voting procedures in the selection of directors, use of proxies for voting, and shareholders' ability to make proposals at shareholder meetings and to call extraordinary shareholder meetings.

Principle II also relates to "fairness" in holding that: "The corporate governance framework should ensure the equitable treatment of all shareholders, including minority and foreign shareholders. All shareholders should have the opportunity to obtain effective redress for violation of their rights." This means that the legal framework should include laws that protect the rights of minority shareholders against misappropriation of assets or self dealing by controlling shareholders, managers or directors. Rules that regulate transactions by corporate insiders and impose fiduciary obligations on directors, managers and controlling shareholders -and mechanisms to enforce those rules, such as shareholder derivative actions -- are some examples.

Transparency: Principle IV states that: "The corporate governance framework should ensure that timely and accurate disclosure is made on all material matters regarding the corporation, including the financial situation, performance, ownership and governance of the company." This recognises that investors and shareholders need information about the performance of the company -- its financial and operating results -- as well as information about corporate objectives and material foreseeable risk factors to monitor their investment. Financial information prepared in accordance with high-quality standards of accounting and audit should be subject to an annual audit by an independent auditor. This provides an important check on the quality of accounting and reporting. (Of course, accounting standards continue to vary widely around the world. Internationally prescribed accounting standards that promote uniform disclosure would enable comparability, and assist investors and analysts in comparing corporate performance and making decisions based on the relative merits.) Information about the company's governance, such as share ownership and voting rights, identity of board members and key executives and executive compensation, is also important to potential investors and shareholders and is a critical component of transparency.

Accountability: Principle V states: "The corporate governance framework should ensure the strategic guidance of the company, the effective monitoring of management by the board, and the board's accountability to the company and the shareholders." This Principle implicates a legal duty of directors to the company and its shareholders. As elected representatives of the shareholders, directors are generally held to be in a fiduciary relationship to shareholders and to the company, and have duties of loyalty and care which require that they avoid self-interest in their decisions and act diligently and on a fully informed basis. Generally, each director is a fiduciary for the entire body of shareholders and does not report to a particular constituency.

This Principle also recognizes that the board is charged with monitoring the professional managers to whom the discretionary operational role has been delegated and holding them accountable in the use of firm assets.14 In this respect, the board provides a mechanism for reducing the agency problem -- described by Adam Smith in 1776 -- that is inherent in the 
separation of ownership and control.15 If the board is to serve as an effective monitor of managerial conduct, however, it must be sufficiently distinct from management to be capable of objectively evaluating management. (A board comprised wholly or primarily of management cannot be expected to effectively minimize agency problems.) This generally requires that some directors are neither members of the management team nor closely related to them through family or business affairs.

Clearly, the quality of corporate governance also depends on the quality of directors. Objective oversight requires the inclusion of professionally competent nonexecutives and independent directors, who have the capability, fiduciary commitment and objectivity to provide strategic guidance and monitor performance on behalf of shareholders. (Holly and Marsha, 1999)

Much has been written about the practices that boards should follow to encourage board effectiveness. In general, board "best practices" suggest that the board should meet often. For most boards, this is at least once per quarter; and usually more frequently. In addition, the effectiveness of directors -- especially non-executives -- depends upon the quality of information that is made available to them. To ensure that "independent oversight" has meaning, directors must have access to important information and such information should be provided in advance of board meetings.

Board committees have provided a useful structure for performing detailed board work. In the U.S. and the U.K. it is common to rely on an audit committee, executive compensation (or remuneration) committee and a nomination committee (and staff them wholly or primarily with non-executives or independent directors).

Responsibility: Principle III translates "responsibility" to mean that: "The corporate governance framework should recognize the rights of stakeholders as established by law and encourage active co-operation between corporations and stakeholders in creating wealth, jobs, and the sustainability of financially sound enterprises." This recognizes that corporations must abide by the laws and regulations of the countries in which they operate, but that every nation must decide for itself the values it wishes to express in law and the corporate citizenship requirements it wishes to impose.

As with good citizenship generally, however, law and regulation impose only minimal expectations as to conduct. Outside of law and regulations, corporations should be encouraged to act responsibly and ethically, with special consideration of the interests of stakeholders, and in particular employees.

Increasingly, corporations recognize that active co-operation between corporations and stakeholders assists corporate performance, and that socially responsible corporate conduct is consistent with the principle of shareholder maximisation.18 In many nations, corporations go well beyond legal requirements in providing health care and retirement benefits, encouraging diversity of race and gender in employment and promotion practices, financially supporting education, and formulating and adopting environmentally friendly technologies. Similarly, many companies strive to avoid activities perceived to be socially undesirable even where not prohibited.

The four principles of corporate governance articulated in the Millstein Report -- fairness, transparency, accountability and responsibility -- as expanded into the five OECD Principles of Corporate Governance require both regulation and private sector initiative for implementation. 
Regulation ensures that minimum standards are met; private codes of conduct and voluntary behaviour can and in many cases should go well beyond minimum legal requirements.

\section{Corporate Governance Framework for SMEs}

The first step is initiating and generating debate among key stakeholders regarding the need for corporate governance and its implications for SMEs. This will help to increase awareness and at the same time build support for developing a framework. It is important that this mechanism be as participatory as possible.

The next step is the development of Code. This process should be conducted through establishment of a committee consisting of representatives from SME Chamber and Securities Exchange Commission. This draft should then be shared with various stakeholders including Institute of Chartered Accountants, Banking Association and Business Associations. It is important that this process be as inclusive and participatory as possible. Therefore extensive and meaningful consultations should be carried-out with all stakeholders so that ownership of the process is built. For example, in Pakistan, the initiative to develop a framework for good corporate governance in Pakistan was taken by the Institute of Chartered Accountants of Pakistan (ICAP) in December 1998. Later, this initiative was also supported by the SEC and a Committee comprising of representatives from the SEC, ICAP, the three Stock Exchanges in Pakistan and Institute of Cost and Management Accountants of Pakistan (ICMAP) was established. A subcommittee was also formed to undertake the task of formulating recommendations for the first Code of Corporate Governance ("the Code") for Pakistan. The committee prepared the first draft of the Code in 2000. The draft Code underwent extensive consultation and public debate under the auspices of the SEC. In this regard, a series of seminars were organized in Karachi, Lahore and Islamabad. The draft Code was also circulated by ICAP to various organizations and was placed on the websites of SEC and ICAP to seek comments and suggestions. Various suggestions were received, which were considered and incorporated in finalizing the Code.

After developing a Code for Corporate governance, the next step is to start the process of capacity building of all stakeholders. In this regard, training workshops should be organized for all stakeholders including the owners of SMEs.

Let us discuss various features of this code which would need to be taken account for at the very beginning. The Code would need to be based on the following principles:

a) Self-regulation i.e. voluntary to adopt rather than enforced

b) Incorporates the particular needs of SMEs

c) Flexible so that it can be adapted to the heterogeneous sectors and sizes of SMEs

d) Not complicated and easy understand for business owners

e) Should be incentives based such as providing tax rebates.

f) Other regulations should be amended to make them compatible with the Code in order to avoid regulatory burden and duplication.

An incentive based corporate governance system will also attract informal enterprises i.e. the ones which are not registered. Informal economies are of considerable size in developing countries. It is therefore important to devise a system for formalizing these enterprises. This will ultimately help in documentation of economy consequently expanding tax. Keeping in view the fiscal deficit in these countries, the incentive based corporate governance framework will ultimately have positive impact on macroeconomic indicators. 


\section{Review of previous studies}

Quite number of studies has been carried out on corporate governance in business transactions in various aspects. In a study on Corporate Governance and Business Ethics for SMEs in Developing Countries: Challenges and Way Forward by Shahnawaz and Islamabad (2008). The paper discusses issues facing SMEs in developing countries and the need for embracing corporate governance and ethical business practices.

This paper concludes that incentives based governance framework would need to be developed in order to encourage these enterprises to adopt good governance practices particularly through tax incentives and award of annual trophy. The paper recommends that SME chambers should be strengthened to become advocates for corporate governance and business ethics amongst its members and also that venture services companies for SMEs need to be established and encouraged in order to develop sustainable and market-driven governance solutions as well as creating ethical business culture.

In another line of study by Dube et al (2011) on corporate governance norm for Small and Medium Enterprises. the study conclude that Corporate Governance for SME is a challenging task keeping in mind the business form and nature of business it is involved in. In India, the activities of SME come under different regulatory agencies as has been discussed in the different parts of the report. Because of that they are already subjected to multiple regulators which, according to researchers, appear arduous for the SME's.

Facility and welfare of SME are mainly regulated by the Ministry of Micro, Small and Medium Scale Enterprises, whereas the business forms are under the control of Ministry of Corporate Affairs. Corporate Governance is mainly an issue pertaining to business form, their efficient and sustainable management. So, logically the Corporate Governance of SME should be a subject matter to be handled by the Ministry of Corporate Affairs and recommends that corporate governance of SME's should be a voluntary action on their part. The researchers strongly believe that there should not be framing of any new regulations for that purpose. But there is a need of creating awareness within the sector for adopting corporate governance and its consequent benefits.

In a similar study on The Impact of Corporate Governance on firm performance in an unstable economic and political environment: Evidence from Sri Lanka by Kumudini and Anona (2009) . The study argues that there was a relationship between the corporate governance initiative and the growth in the performance of firms from 2003 to 2007 as well examined the relationship between corporate governance practices and firm performance. The paper concludes that the results of this study and the literature report that good corporate governance is an important factor in determining firm performance. According to them that many business failures are due to the boards' inability to address the overall company performance in an effective and consistent manner. The reason for that lies in the structure of the board, particularly in relation to the structure of the decision making process which needs to be reformed to enable companies to focus on sustaining high performance in the face of a rapidly changing environment (Cutting \& Kouzmin 2000). This study reported significant relationships between corporate governance practices of separate leadership structure, a majority of non-executive directors and board committees, and firm performance. The growth in the economy, despite 
the adverse conditions, is partly due to good governance practices adopted by firms. Thereby recommends that Survival strategies of the corporate sector to maintain a healthy bottom line amidst the economic and political adversities were extremely important to the economy of Sri Lanka.

In this paper, the paper intends determine the extent at which corporate governance can enhance transparency and accountability that will enable the enterprises improve in their operations so that both the organizational objectives and their social obligations can be attained effectively.

\section{Hypotheses}

Ho: Corporate governance has not contributes significantly in ensuring accountability and transparency in order to improve performances of an enterprise.

Ho: Corporate governance does not facilitate the organizations in achieving their social responsibilities to its environment.

\section{Methodology}

Survey research method was adopted and questionnaire was administered on a random the ninety eight (98) selected sample of employees and management of seven (7) Small and Medium Enterprises in Onitsha, Anambra state. Judgmental sampling technique was used in selecting the seven Small and Medium Enterprises.

In collecting of the data distributed, seventy four (74) out of ninety eight (98) questionnaires were complete and returned. This represents $76 \%$.

\subsection{Data Analysis}

\subsubsection{Frequency Table}

Corporate governance helps to militates against the financial fraud in an organization.

Table 4.1: Shows whether corporate governance helps to militates against the financial fraud in an organization

\begin{tabular}{|c|c|c|c|c|}
\hline & Frequency & Percent & Valid Percent & $\begin{array}{l}\text { Cumulative } \\
\text { percent }\end{array}$ \\
\hline $\begin{array}{ll}\text { Valid } & \text { Agree } \\
& \text { Strongly Agree } \\
\text { Total }\end{array}$ & $\begin{array}{l}16 \\
58 \\
74\end{array}$ & $\begin{array}{l}21.6 \\
78.4 \\
100.0\end{array}$ & $\begin{array}{l}21.6 \\
78.4 \\
100.0\end{array}$ & $\begin{array}{l}21.6 \\
100.0\end{array}$ \\
\hline
\end{tabular}

Source: field survey 2013

Corporate governance ensures against the corruption and massive looting of the assets of enterprises.

Table 4.2: Show whether corporate governance ensures against the corruption.

\begin{tabular}{|c|l|l|l|l|}
\hline & Frequency & Percent & Valid Percent & $\begin{array}{l}\text { Cumulative } \\
\text { percent }\end{array}$ \\
\hline Valid Strongly Disagree & 1 & 1.4 & 1.4 & 1.4 \\
Undecided & 8 & 10.8 & 10.8 & 12.2 \\
Agree & 5 & 6.8 & 6.8 & 18.9 \\
Strongly Agree & 60 & 81.1 & 81.1 & 100.0 \\
\hline
\end{tabular}




\begin{tabular}{|c|l|l|l|l|}
\hline Total & 74 & 100.0 & 100.0 & \\
\hline
\end{tabular}

Source: field survey 2013

Good governance ensures the establishment of a set of corporate values and clear lines of responsibility and accountability is assured.

Table 4.3: Shows whether Good governance ensures corporate values and clear lines of responsibility.

\begin{tabular}{|l|l|l|l|l|}
\hline & Frequency & Percent & Valid Percent & $\begin{array}{l}\text { Cumulative } \\
\text { percent }\end{array}$ \\
\hline Quarterly & 6 & 8.1 & 8.1 & 8.1 \\
Yearly & 68 & 91.9 & 91.9 & 100.0 \\
& 74 & 100.0 & 100.0 & \\
\hline
\end{tabular}

Source: field survey 2013

Good corporate governance is an essential for internal control system.

Table 4.4: show whether good corporate governance is an essential for internal control system.

\begin{tabular}{|l|l|l|l|l|}
\hline & Frequency & Percent & Valid Percent & $\begin{array}{l}\text { Cumulative } \\
\text { percent }\end{array}$ \\
\hline Valid Strongly Disagree & 1 & 1.4 & 1.4 & 1.4 \\
Undecided & 1 & 1.4 & 1.4 & 2.7 \\
Agree & 6 & 8.1 & 8.1 & 10.8 \\
Strongly Agree & 66 & 89.2 & 89.2 & 100.0 \\
Total & 74 & 100.0 & 100.0 & \\
\hline
\end{tabular}

Source: field survey 2013

With corporate governance management has clear strategies for efficient operation of an enterprise.

Table 4.5: Shows whether corporate governance will enable management to have clear strategies for efficient operation of an enterprise.

\begin{tabular}{|c|l|l|l|l|}
\hline & Frequency & Percent & Valid Percent & $\begin{array}{l}\text { Cumulative } \\
\text { percent }\end{array}$ \\
\hline Valid Undecided & 1 & 1.4 & 1.4 & 1.4 \\
Agree & 4 & 5.4 & 5.4 & 6.8 \\
Strongly Agree & 69 & 93.2 & 93.2 & 100.0 \\
Total & 74 & 100.0 & 100.0 & \\
\hline
\end{tabular}

Source: field survey 2013

Corporate governance provides a well-defined and acceptable division of responsibilities among various cadres within the organizations.

Table 4.6: Shows whether corporate governance provides a well-defined and acceptable division of responsibilities among various cadres within the organizations.

\begin{tabular}{|c|l|l|l|l|}
\hline & Frequency & Percent & Valid Percent & $\begin{array}{l}\text { Cumulative } \\
\text { percent }\end{array}$ \\
\hline Valid Strongly Disagree & 3 & 4.1 & 4.1 & 4.1 \\
Disagree & 1 & 1.4 & 1.4 & 5.4 \\
Undecided & 1 & 1.4 & 1.4 & 6.8 \\
Agree & 3 & 4.1 & 4.1 & 10.8 \\
\hline
\end{tabular}




\begin{tabular}{|l|l|l|l|l|}
\hline Strongly Agree & 66 & 89.2 & 89.2 & 100.0 \\
Total & 74 & 100.0 & 100.0 & \\
\hline
\end{tabular}

Source: field survey 2013

Good corporate governance promotes strategic guidance of the enterprise for effective monitoring of their environment.

Table 4.7: Shows whether good corporate governance promotes strategic guidance of the enterprise for effective monitoring of their environment.

\begin{tabular}{|l|l|l|l|l|}
\hline & Frequency & Percent & Valid Percent & $\begin{array}{l}\text { Cumulative } \\
\text { percent }\end{array}$ \\
\hline Valid Undecided & 2 & & & 2.7 \\
Agree & 14 & 18.9 & 18.9 & 21.6 \\
Strongly Agree & 58 & 78.4 & 78.4 & 100.0 \\
Total & 74 & 100.0 & 100.0 & \\
\hline
\end{tabular}

Source: field survey 2013

Corporate governance is useful and necessary for carrying out goals and objectives as well as their social responsibilities of an enterprise.

Table 4.8: Shows whether corporate governance is useful and necessary for carrying out goals and objectives as well as their social responsibilities.

\begin{tabular}{|l|l|l|l|l|}
\hline & Frequency & Percent & Valid Percent & $\begin{array}{l}\text { Cumulative } \\
\text { percent }\end{array}$ \\
\hline Valid Agree & 6 & 8.1 & 8.1 & 8.1 \\
& 68 & 91.9 & 91.9 & 100.0 \\
Strongly Agree & 74 & 100.0 & 100.0 & \\
\hline
\end{tabular}

Source: field survey 2013

Corporate governance ensures efficient operations and performance in organizations.

Table 4.9: Shows whether corporate governance ensures efficient operations and performance in organizations.

\begin{tabular}{|c|l|l|l|l|}
\hline & Frequency & Percent & Valid Percent & $\begin{array}{l}\text { Cumulative } \\
\text { percent }\end{array}$ \\
\hline Valid Undecided & 1 & & & 1.4 \\
Agree & 6 & 4.1 & 1.4 & 9.5 \\
Strongly Agree & 67 & 8.1 & 8.1 & 100.0 \\
Total & 74 & 90.5 & 90.5 & \\
\hline
\end{tabular}

Source: field survey 2013

Corporate governance will enable the organization to show concern to their environment.

Table 4.10: Shows whether corporate governance will enable the organization to show concern to their environment. 


\begin{tabular}{|l|l|l|l|l|}
\hline & Frequency & Percent & Valid Percent & $\begin{array}{l}\text { Cumulative } \\
\text { percent }\end{array}$ \\
\hline Valid Strongly Disagree & 2 & 2.7 & 2.7 & 2.7 \\
Disagree & 3 & 4.1 & 4.1 & 6.8 \\
Agree & 4 & 5.4 & 5.4 & 12.2 \\
Strongly Agree & 65 & 87.8 & 87.8 & 100.0 \\
Total & 74 & 100.0 & 100.0 & \\
\hline
\end{tabular}

Source: field survey 2013

Corporate governance ensures that society is taken of in order to promote their welfare.

Table 4.11: Shows whether corporate governance ensures that society is taken of.

\begin{tabular}{|l|l|l|l|l|}
\hline & Frequency & Percent & Valid Percent & $\begin{array}{l}\text { Cumulative } \\
\text { percent }\end{array}$ \\
\hline Valid Strongly Disagree & 1 & 1.4 & 1.4 & 1.4 \\
& 1 & 1.4 & 1.4 & 2.7 \\
Agree & 72 & 97.3 & 97.3 & 100.0 \\
Strongly Agree & 74 & 100.0 & 100.0 & \\
\hline Total & & & \\
\hline
\end{tabular}

Source: field survey 2013

Business objectives and their social obligations are defined clearly such that decisions are made and actions taken by the appropriate people and these decisions appropriately co-ordinate.

Table 4.12: Shows whether Business objectives and their social obligations are defined clearly.

\begin{tabular}{|c|l|l|l|l|}
\hline & Frequency & Percent & Valid Percent & $\begin{array}{l}\text { Cumulative } \\
\text { percent }\end{array}$ \\
\hline Valid Disagree & 1 & 1.4 & 1.4 & 1.4 \\
Agree & 2 & 2.7 & 2.7 & 4.1 \\
Strongly Agree & 71 & 95.9 & 95.9 & 100.0 \\
Total & 74 & 100.0 & 100.0 & \\
\hline
\end{tabular}

Source: field survey 2013

\section{Test of Hypotheses}

The results of the hypothesis formulated for the purpose of this study are now presented.

\subsection{Hypothesis I:}

$\mathrm{H}_{0}$ : Corporate governance has not contributes significantly in ensuring accountability and transparency in order to improve performances of an enterprise.

Model summary

\begin{tabular}{|l|r|r|r|r|}
\hline Model & $\mathrm{R}$ & \multicolumn{1}{|c|}{ R Square } & Adjusted R Square & $\begin{array}{c}\text { Std. Error of the } \\
\text { Estimate }\end{array}$ \\
\hline 1 & $.201^{\mathrm{a}}$ & .040 & -.015 & .41765 \\
\hline
\end{tabular}

Predictors: (Constant), management, staff. And customers 
ANOVA b

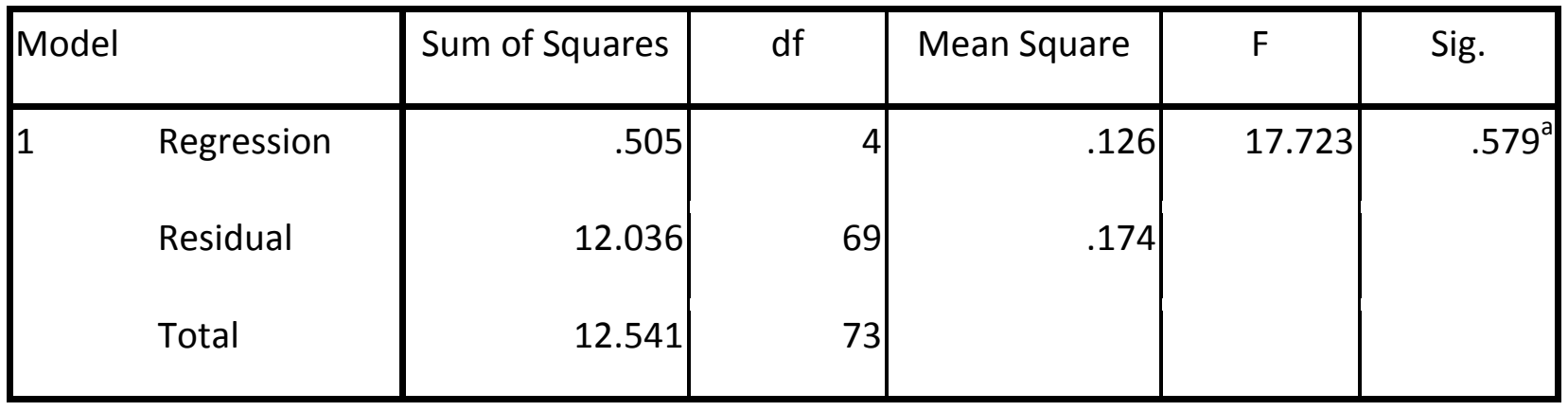

a. Predictors: (Constant), management, staff. And customers

b. Dependent Variable: Corporate governance has contributes significantly to improve performances of an enterprise.

Model Summary

\begin{tabular}{|l|r|r|r|r|}
\hline Model & R & R Square & Adjusted R Square & \multicolumn{2}{|c|}{$\begin{array}{c}\text { Std. Error of the } \\
\text { Estimate }\end{array}$} \\
\hline 1 & $.201^{\mathrm{a}}$ & .040 & -.015 & .41765 \\
\hline
\end{tabular}

b. Dependent Variable: By assessments corporate governance contributes significantly in ensuring accountability and transparency.

Model summary

\begin{tabular}{|l|r|r|r|r|}
\hline Model & R & R Square & Adjusted R Square & $\begin{array}{c}\text { Std. Error of the } \\
\text { Estimate }\end{array}$ \\
\hline 1 & $.201^{\mathrm{a}}$ & .040 & -.015 & .41765 \\
\hline
\end{tabular}

\section{Decision Criterion}

Reject the null hypothesis if computed $F$ value $>F$ table value otherwise accept. Since $(17.723)$ is greater than the table value (3.659), accept the alternative hypotheses which states that corporate governance contributes significantly in ensuring accountability and transparency in order to improve performances of an enterprise.

\subsection{Hypothesis two}

$\mathrm{H}_{\mathrm{o}}$ : Corporate governance does not facilitate the organizations in achieving their social responsibilities to its environment.

Model Summary

\begin{tabular}{|l|r|r|r|r|}
\hline Model & R & R Square & Adjusted R Square & $\begin{array}{c}\text { Std. Error of the } \\
\text { Estimate }\end{array}$ \\
\hline 1 & $.089^{\mathrm{a}}$ & .068 & .55 & .91788 \\
\hline
\end{tabular}


a.

Predictors:

(Constant), management, staff. And customers

ANOVA b

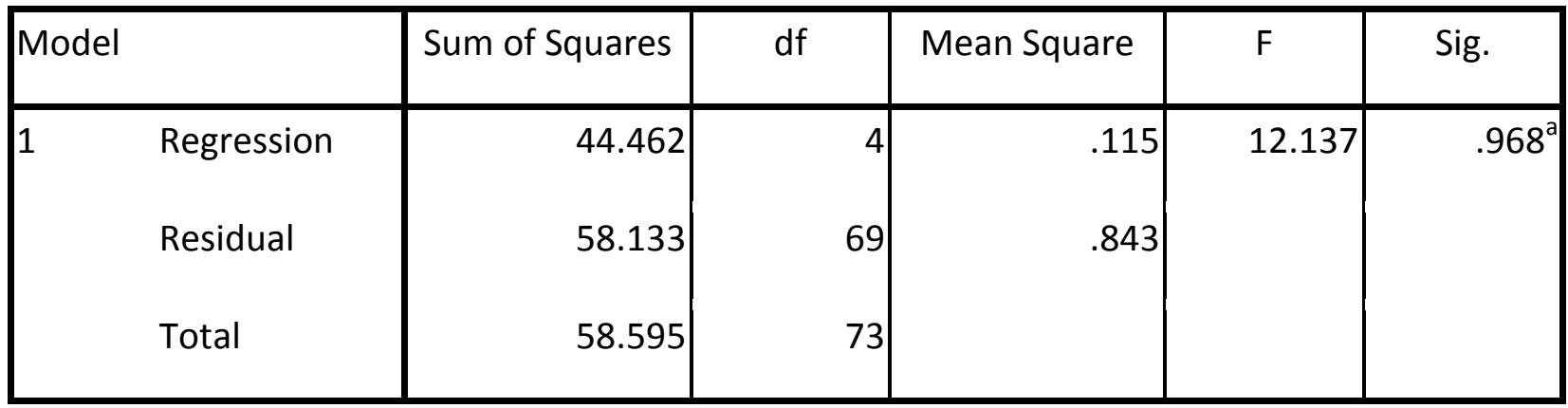

a. Predictors: (Constant), management, staff. And customers

b. Dependent Variable: Corporate governance facilitates the organizations in achieving their social responsibilities.

Model Summary

\begin{tabular}{|l|r|r|r|r|}
\hline Model & $\mathrm{R}$ & \multicolumn{1}{|c|}{ R Square } & Adjusted R Square & $\begin{array}{c}\text { Std. Error of the } \\
\text { Estimate }\end{array}$ \\
\hline 1 & $.089^{\mathrm{a}}$ & .068 & .55 & .91788 \\
\hline
\end{tabular}

\section{Decision Criterion:}

Reject the null hypothesis if computed $F$ value $>F$ table value otherwise accept. Since (12.137) is greater than the table value (3.659), accept the alternative hypothesis which states that 'Corporate governance facilitates to an extent in achieving their social responsibilities to its environment.

\section{Summary of Findings, Conclusions and Recommendations}

\subsection{Summary of Findings}

Having analyzed the data collected, the paper drawn the following major findings;

1. Corporate governance has contributes significantly in ensuring accountability and transparency in order to improve performances of an enterprise.

2. Corporate governance facilitates to an extent in achieving their social responsibilities to its environment.

3. Good corporate governance promotes strategic guidance of the enterprise for effective monitoring of their environment.

4. Corporate governance is useful and necessary for carrying out goals and objectives as well as their social responsibilities of an enterprise.

\subsection{Conclusions}

This paper has attempted to appraisal the impact corporate governance issues in enhancing transparency and accountability in small and medium enterprises. This study reviewed various forms including journal papers, articles and other relevant materials. Based on this, the paper 
discovered that corporate governance has contributes significantly in ensuring accountability and transparency in order to improve performances of an enterprise at the same time facilitates to an extent in achieving their social responsibilities to its environment.

Finally, corporate governance assists in provides structure through which the objectives of the enterprises are set and means of attaining those objectives and monitoring performances all to ensure effectiveness in operations and efficiency in their services.

\subsection{Recommendations}

Having made some findings, the researcher recommends the following;

1. Management should incorporate well-defined ethics investigation processes into their policies and strategic to facilitates efficiency in their operations.

2. There should be well-defined disclosures on organization's role as to provide information on who gets what, and what purpose and the roles played by them in assuming their social responsibilities.

\section{References}

Shahnawaz M. and Islamabad P. (2008) "Corporate Governance and Business Ethics for SMEs in Developing Countries: Challenges and Way Forward"

Dube I. Dube D. and Pulak M. (2011) “Corporate Governance Norm for SME” Journal of Public Administration and Governance ISSN 2161-7104 2011, Vol. 1, No. 2

Kumudini H. and Anona A. (2009) "The Impact of Corporate Governance on firm performance in an unstable economic and political environment: Evidence from Sri Lanka"

Spanos, LJ 2005, 'Corporate Governance in Greece: Developments and Policy Implcations', Corporate Governance, vol. 5, no. 1, pp. 15-30.

Cadbury, A 1992, Report on the Committee on the Financial Aspects of Corporate Governance, Gee, London.

Rezaee, Z 2009, Corporate Governance and Ethics, John Wiley \& Sons, Inc, USA.

Berle, A \& Means, G 1932, The Modern Corporation and Private Property, MacMillan, New York. Berle, AA \& Means, G 1932, The modern Corporation and Private Property, New York.

Jensen, MC \& Meckling, WH 1976, 'Theory of Firm: Managerial Behaviour, Agency Costs and Ownership Structure', Journal of Financial Economics, vol. 3, pp. 305-50.

Davis, JH, Schoorman, FD \& Donaldson, L 1997, 'Towards a Stewardship Theory of Management', Academy of Management Review, vol. 22, pp. 20-47.

Davis, SM 2002, 'Leading Corporate Governance Indicators', in LC Keong (ed.), Corporate Governance An Asia-Pacific Critique, Sweet \& Maxwell Asia, Hong Kong

Holly j. G.and Marsha e. S.(1999) "corporate governance: what it is and why it matters" 9th international anti-corruption conference, 10-15 October 1999, Durban, South Africa 